\title{
The Academic Procrastination in Junior High School Students' Mathematics Learning: A Qualitative Study
}

\author{
Dahlia Novarianing Asri ${ }^{1,2}$, Punaji Setyosari ${ }^{1}$, Imanuel Hitipeuw ${ }^{1} \&$ Tutut Chusniyah $^{1}$ \\ ${ }^{1}$ Postgraduate Program, Universitas Negeri Malang, Malang, Indonesia \\ ${ }^{2}$ Department of Guidance and Counseling, Faculty of Teachers Training and Education, Universitas PGRI \\ Madiun, Madiun, Indonesia \\ Correspondence: Dahlia Novarianing Asri, Department of Guidance and Counseling, Universitas PGRI Madiun, \\ 85 Setiabudi Street, Madiun, East Java, Indonesia. Tel: 62-813-3553-0296. E-mail: novarianing@gmail.com
}

Received: March 21, 2017

Accepted: April 27, 2017

Online Published: August 27, 2017

doi:10.5539/ies.v10n9p70

URL: https://doi.org/10.5539/ies.v10n9p70

\begin{abstract}
Among the main causes of low learning achievement in mathematics learning is a delayed behavior to do tasks, commonly called academic procrastination. The objectives of this research are to describe and to explain the causal factors and consequences of academic procrastination in learning mathematics for junior high school students. This research was conducted for more than five months. The research took place at six junior high schools in Madiun Regency. The research approach was a qualitative descriptive. The types of data sources were six mathematics teachers and six students, in-class mathematics learning activities, and documents. The data collection techniques were (1) questionnaire, (2) documentation, (3) passive role observation, and (3) in-depth interviews. The data were analyzed using an interactive model, which was implemented in two stages. They are at the time or during the course of data collection and after the data collection. The results of data analysis show that academic procrastination is caused by several factors. They are assumption that the tasks assigned are not important, too burdensome, and difficult to work, insufficient knowledge, too perfectionist, bad management of learning, lack of self-regulation, stress and fatigue, lack of social support, indiscipline teachers, and inconducive school culture. Academic procrastination, most importantly, leads to low learning achievement.
\end{abstract}

Keywords: academic procrastination, mathematics learning

\section{Introduction}

For most students, mathematics is one of the most difficult and scariest lessons. The National Council of Teachers of Mathematics (cited in Bell and Pape, 2014) describes five standards used in the process of studying Mathematics in schools, i.e., problem-solving, reasoning and proof, communication, connections, and representation. To perform the process standards, as Sutton (cited in Asikhia, 2010) puts, it is not easy to understand mathematics concepts which involve cognitive and affective aspects. Students' worldview about mathematics leads to the low learning achievement. This notion is supported by the results of the 2011 Trends in International Mathematics and Science Study (TIMSS) research in the fields of mathematics and science for the second graders of junior high schools, indicating that more than $95 \%$ of students in Indonesia are merely able to reach the medium level. Indonesian students are currently ranked the lowest in terms of (1) the ability to understand complex information, (2) theory, analysis and problem solving, (3) the use of tools, procedures, and trouble shootings, and (4) conducting investigations.

The low learning achievement of mathematics results from many factors, among which is the delayed behavior of doing tasks called academic procrastination. It is defined as a behavior that deliberately delays or postpones doing a work. Students who procrastinate do not have a stimulus to do an activity at a time (Schraw, Wadkins, \& Olafson, 2007) and many of them experience negative consequences of academic procrastination, i.e. the low achievement (Burka \& Yuen, 1983; Ferrari, Johnson, \& McCown, 1995; Knaus, 1998; Tice \& Baumeister, 1997) and the low attendance in the class until dropouts (Knaus, 1998).

Asri (2015) conducted a preliminary study on the academic procrastination in the learning of mathematics for the second graders of junior high schools across Madiun Regency, East Java, Indonesia. The results show that low levels of mathematics learning achievement for junior high school students are influenced by the academic 
procrastination. They do not realize how important the tasks given by their class teacher are. They prefer to spend more time for fun activities than to do the academic tasks. It happens since they consider Math tasks not fun, difficult, and they need more power and huge thoughts to finish the tasks.

Quantitative research in recent decades discusses the causes and effects of academic procrastination and finds internal and external psychosocial factors responsible for its emergence. The internal ones are: (1) personality-related which includes negative self-image, avoidance, and perfectionism (Zeenath \& Orcullo, 2012; Patrzek, Grunschel, \& Fries, 2012; Procee, Kamphorst, Wissen, \& John-Jules, 2013; Pychyl, Coplan, \& Reid, 2002; Saleem \& Rafique, 2012), (2) competence-related which covers lack of knowledge, regulation of low self-esteem, and lack of study skills, (3) affective which refers to anxiety, frustration, boredom, feelings of anxiety, shame, and guilt (Deniz, Traz, \& Aydogen, 2009; Haghbin, Mccaffrey, \& Phychyl, 2012; Vahedi, Farrokhi, Gahramani, \& Issazadegan, 2012; Haycock, McCarthy, \& Skay, 1998), (4) cognitive which concerns on fear, lack of internal motivation, and failure of self-regulation (Park \& Sperling, 2012; Asri, 2015), (5) learning history which consists of behavioral learning and negative learning experience, (6) physical and mental health, (7) perception of the characteristics of academic assignments viewing the task as an enemy, or as difficulty, or otherwise it is perceived as important to work with (Procee et al., 2013), (8) lack of the scale of priorities, (9) poor time management skills, and (10) the selection of coping strategies used (Procee et al., 2013; Asikhia, 2010; Tsai, Shen, \& Lee, 2011; Seperiah \& Lotf, 2011). While the external ones cover school-related matters such as the quality of teachers, peer influences, and external conditions of the school (Zeenath \& Orcullo, 2012; Patrzek et al., 2012) and the style of parenting (Pychyl et al., 2002; Zakeri, Esfahani, \& Razmjoee, 2013; Vahedi \& Mortazanajad 2009; Milgram \& Toubiana, 1999).

In addition, some literature reviews indicate the low achievement (Burka and Yuen, 1983; Ferrari et al., 1995; Knaus, 1998; Tice \& Baumeister, 1997) and the low attendance classroom until dropouts (Knaus, 1998) are the consequences of procrastination. In addition, Tice and Baumeister (1997) suggest that health is also a consequence of procrastination. The research elaborates the level of stress and physical symptoms which appear during lectures in a semester.

Problems of academic procrastination in the learning Math causes serious actions. Teachers should attempt to change students' perspective on Math into an unthreatening school subject. As well, they are expected to give more attention on academic procrastination faced by the students. By so doing, it is hoped that academic procrastination in learning Math can be curved.

The present study, likewise, cultivates some triggered factors and the consequences of academic procrastination in the learning Math. The results can be used by the teachers to design strategies to decrease students' academic procrastination.

\subsection{Research Objectives}

The aim of this study was to describe and explain the reasons pertaining to students' academic procrastination in learning Mathematics and its consequences on the academic procrastination experienced by junior high school students, addressing the following research questions:

a) What are the factors that cause students' academic procrastination in learning mathematics?

b) What are the consequences of this academic procrastination for students?

\section{Methods}

This research had been conducted for more than five months. The research settings of place were (1) SMPN 1 Jiwan Madiun, (2) SMPN 3 Kare Madiun, (3) SMPN 1 Wungu Madiun, (4) SMPN 2 Mejayan Madiun, (5) SMPN 2 Geger Madiun, and (6) SMPN 1 Saradan Madiun. These schools were selected based on school level variability, geographical factor, and the students' academic potentiality.

Using a qualitative-descriptive approach, this research puts more emphasis on research observations of interactions between teacher and students in learning mathematics at the schools. Moreover, documents related to the research problems were analyzed as well. The data in this research were a number of information closely connected to students' academic procrastination in learning mathematics. The types of data sources include (1) informants, consisting of 12 key informants of six mathematics teachers and six students from each school who studied mathematics, (2) events or activities during the mathematics instructions in the classrooms, and (3) documents in the forms of mathematics teaching materials used by teachers, the tasks done by the students, the results of data assessment to track the records of the students, and other related documents. The sample was taken by utilizing purposive sampling since it was related to the research purposes and problems. Based on the characteristics and types of data required, the research data collection techniques were (1) questionnaires, (2) 
documentation, (3) passive observations, and (3) in-depth interviews.

To analyze the data, an interactive model was carried out in two stages. They are at the time or during the course of data collection and after the data collection. This data analysis was done through the three flows of activities that took place simultaneously, i.e. (1) data reduction, (2) data presentation and (3) conclusion/verification (Miles, Huberman, \& Saldana, 2014).

The techniques selected by the researchers to check the data validity include (1) extending the participation of researchers, (2) making observations diligently and carefully, (3) performing a triangulation of data sources by comparing the data analysis results from questionnaires, observations, interviews, the contents of documents, and (4) examining the findings through group discussions (a focus-group discussion).

\section{Results}

Referring to the observation and analysis of documents that form the syllabus and mathematics learning, it is known that almost all teachers choose the project-based learning method to deliver their learning materials. To them, the implementation of project-based learning method seems appropriate because it can associate the materials being taught to the surrounding situation in various contexts. In the interview, they also state that the project-based learning method can improve students' mastery of concepts and provide plenty of time for students to think, design, investigate, analyze, conclude the answers of questions, and collaborate through the projects they give.

The results of survey using a questionnaire involving 154 students at six schools show that $72(46.8 \%)$ students never put off the task, $58(37.7 \%)$ had put off tasks, and 24 (15.5\%) always put off doing their tasks. As many as 82 students $(53.2 \%)$ experience the academic procrastination in learning mathematics. The researchers' in-class observations prove that fewer than half of them have completed the task on time. Further, it is found that students doing the in-class task cheat their tasks before the lesson begins.

The interviews with students show that most of them are unaware of the importance of tasks given by the teachers to increase academic achievement. They think that the tasks are time-consuming especially when they are at home. Most of them also claim that they have many activities to do outside of school subjects, such as hanging out with friends to spend leisure time. In consequence, the assignment given by teachers cannot be completed on time. In addition, the majority of them state that the assignments are too burdensome because they also have many other tasks to do.

Furthermore, the high level of academic procrastination is partly influenced by the students' personality. Most student informants state that the tasks assigned by teachers are difficult to do that make them often get confused. As a result, they tend to avoid the school work and prefer to do other activities just for fun, for example, listening to music, and hanging out with friends. This is a form of escapism as they often feel depressed and overwhelmed when they are completing school assignments.

Regardless of the fact, in teachers' perspectives, academic procrastination is not only experienced by underperformed students but also by those who have good learning performances. Spending more time, students become perfectionistic in doing tasks resulting in perfect results but late submissions. As the observation results indicate, the tasks presented by perfectionistic students are better than those by others, but they still experience the academic procrastination.

The observation results of the students' learning behavior indicate that students with high academic procrastination do not have good learning management. They only learn when they are dealing with exams or formative tests and do not have schedules for continuous learning. For them, learning and doing schoolwork are tedious and difficult. Consequently, they think that they have insufficient knowledge to do assignments. Academic procrastination is also caused by their low self-regulated learning.

In this sense, students' self-regulated learning, along with high levels of academic procrastination, is lower than that of students who have low self-regulated learning. This is because students who have high self-regulated learning will be attracted to learn the materials being taught, prepare for learning in the classroom, and participate fully by asking questions or expressing ideas in class discussions. When doing a homework or academic work, students who have self-regulated learning will clarify the difficulties encountered, find the basic idea, sum up the materials they have read, and link theories to experiences. Conversely, students whose self-regulated learning is low not only fail to implement effective learning strategies, but also experience academic procrastination.

Some student informants claim that homework ignorance or delay was also caused by the personal mood. Under stressed situations, they tend to be lazy to learn and go out of the house to look for activities that can reduce the 
stress. Such situations are temporary in nature because by not doing the task, they will be anxious and fearful of teachers' sanction and, even worse, will get a strike. Doing the schoolwork on an ongoing basis, especially in the form project tasks is time-consuming and leads to to the physical fatigue. In this situation, they either get exhausted or tend to be lazy to learn. This makes them late to hand in their school works.

Academic procrastination in learning mathematics is also caused by external factors. Inconducive learning situations at home can cause academic procrastination. Several student informants with high academic procrastination emphasize that their parents are not strict in applying the pattern and discipline of learning at home. For example, parents never learn to control the development of their children, nor do they check whether or not the children have regular homework to do. The children's learning progress is only viewed from the school grades obtained at the end of the semester. The students with low procrastination, in fact, badly need social support and attention from parents and the environment.

The teacher-related factors also importantly contribute to the students' academic procrastination. A good teacher should be able to give an example of discipline to the students and pay more attention to tasks done by the students. Teachers should encourage them to organize and direct themselves, adjust and control themselves especially in completing the tasks assigned. In contrast, academic procrastination mostly happens because teachers are lack of good academic competence and discipline. The teachers pay less attention to the students' tasks; even they never give sanction to students who commit academic procrastination. Teachers are required to be discipline in managing the teaching hours.

Academic procrastination in learning mathematics is also influenced by the school culture. Of the six schools surveyed, two of them do not apply discipline well. As a result, the academic culture in the schools is bad. For example, a school has nothing to do with well-managed learning hours; it does not sanction the students and teachers who come late to school, and is not able to create a culture of achievement to the school. In the four schools that have good academic culture, it is hard to find a high level of academic procrastination compared to those of two schools having bad academic school culture. Of the eighty two students who commit the academic procrastination, forty seven of them (57.3\%) are from the two schools that have bad school culture.

The high level of students' academic procrastination leads to the low achievement in learning mathematics. The interviews with teachers and the analysis results of learning documents of students' mathematics achievements show that eighty two students who commit the academic procrastination have an average grade of 7.40 in mathematics subject, while seventy two students who never commit the academic procrastination have an average grade of 8.10 . Thus, high academic procrastination results in the students' low achievement in learning mathematics at the schools.

\section{Discussion}

The academic procrastination is mainly caused by several factors namely assuming that the task is not important, too burdensome, difficult to do, and students are lack of knowledge, too perfectionist, lack of time management to learn, lack of self-regulation, stress and fatigue, lack of social support, indiscipline teachers, and incondusive school culture. The research findings significantly correlate to the results of research conducted by Patrzek et al. (2012) who studied the causes of academic procrastination including (1) personality-related antecedent, (a negative self-image), (2) competence-related (a deficient self-regulation), (3) affective (anxiety), (4) cognitive (worries), (5) learning history (a negative learning experience), (6) mental and physical state (an illness), and (7) perceived task characteristic (amount).

The academic procrastination caused by personality-related factors happens to the students who have a habit of procrastination and it is regarded as a personality trait. Traits are assumed to be a response to what is called a relatively sedentary work emerging from students themselves when they faced with a variety of situations such as fear of failure, test anxiety, learning stress and depression identified as dimensions of anxiety or emotional instability. The test anxiety or fear of failure is associated with a procrastinated behavior and a simultaneously raised subjective discomfort. The academic procrastination as such is a form of students' perfectionism. To understand the relationship between perfectionism and procrastination is to consider the role of family environment as Missildine (in Ferrari et al., 1995) states that the role of unrealistic and overly indulgent parents will affect the relationship between procrastination and perfectionism.

In line with students' delayed tasks due to their perception of the task-related characteristics, there are some points to consider namely the task is not important, or too burdensome and difficult to do. This is a misperception in perceiving the schoolwork, for example, overviewing the task as a heavy burden (the unpleasant evasiveness of the task) as well as the fear of failure leading students to incompetence to accomplish the task ultimately without any delays anymore. To avoid the emotional consequences of this failure, 
procrastinators begin to delay the task until they cannot complete it satisfactorily (Ellis \& Knaus, cited in Ferrari et al., 1995).

Students who are lack of time management skills tend to blame the time as a determinant factor that influences the poor quality of the task being completed. This problem needs an intervention through teaching and learning skills and approaches that focus more on time management and scheduling (Procee, et al., 2013; Eerde, 2003; Gafni \& Geri, 2010).

Instead, academic procrastination is caused by low self-regulated learning. The occurrence of procrastination indicates failure in self-regulation learning. Students who have self-regulation in learning or studying are able to set goals, plan, and use effective learning strategies. Conversely, students who have low self-regulation learning often fail to implement effective learning strategies. Expanding the view that the academic procrastination is a form of failure in self-regulation, some researchers suggest that self-regulation is the source of procrastination. A procrastinator may show a lack of self-regulation in three areas: cognitive, motivational, and behavioral. Self-regulation is a key to understand procrastination. A low self-esteem corresponds to a high level of procrastination. In this case teachers play an important role to manage the self-regulation teaching in the classroom (Asikhia 2010; Babadogan 2010; Behrozi, Yeilagh, \& Mansourian, 2013; Klassen, Krawchuck, \& Rajani, 2008; Motie, Heidari, \& Sadhegi, 2013; Park \& Sperling, 2012; Wolters, 2003).

The results of such studies show that stress and fatigue are two factors triggering academic procrastination and this thesis is supported by Tice and Baumeister (1997) who state that the health factors contribute to the cause of procrastination. In addition, the level of stress and physical symptoms appear during the semester. Comparing to non-procrastinator students, at the beginning of the semester, procrastinators show low levels of stress and other psychological symptoms, but these symptoms will increase at the end of the semester.

Academic procrastination is also caused by external factors, namely the lack of social support, indiscipline teachers, and inconducive school culture. The results of this research is supported by the results of a previous study conducted by Patrzek et al. (2012) and Zeenath \& Orcullo (2012) that show academic procrastination caused primarily by the private life (lack of social networks), and the school-related factor (teachers' quality). In an environment of education, although teaching is held in a different class with a different teacher, school culture as a whole has the same things in common. School culture at certain schools will give different results such as students' achievement, students' aggressiveness, lying behaviors, school crime, attachment, social interaction, and fights (Hoy \& Hannum, 1997; G. Gottfredson, D. Gottfredson, Payne, \& N. Gottfredson 2005; Wilson 2012; Libbey, 2004). School culture includes disciplines applied at school, feeling safe when students are at school, learning outcomes, social relationships, school facilities, and students' feelings toward the school that can affect the environment, behavior, and students' learning, and increasing social interaction, and positive behavior organized in the school environment (Zullig, Koopman, Patton, \& Ubbes, 2010). In the context of academic culture at school, teachers can implement the commitment to students (affiliated teachers), and provide the facilities and infrastructure in teaching and learning processes. A healthy school culture will improve students' achievement, and ultimately affect the low academic procrastination (Hoy \& Hannum, 1997).

In addition, academic procrastination leads to low learning achievement in Mathematics (Burka \& Yuen, 1983; Ferrari et al., 1995; Knaus, 1998; Tice \& Baumeister, 1997) and the low attendance in the class until dropouts (Knaus, 1998). Furthermore, Burka and Yuen (1983) add that an emotional component has some consequences for academic procrastination. When people realize that they do delay in doing the task, they will experience a number of internal feelings such as inadequate, panic, anxiety, cheating, tense, and guilt.

\section{Conclusion}

Academic procrastination in learning Mathematics is caused by such factors as assumption that the tasks are not important, too burdensome and difficult to work, insufficiency of knowledge, being too perfectionist, poor learning time management, lack of self-regulation, stress and fatigue, inconducive social support, indiscipline teachers, and unsupported school culture. It, what matters most, contributes to low learning achievement.

These findings might help teachers both school administrators to plan and take actions. Since Mathematics has to be taught in various fun and interesting way, and it can be applied in the daily activities, teachers, then have to change their conventional learning strategies into students' center-learning ones. They could use effective learning strategies, or project based learning, for example. This can encourage students to conduct an in-depth investigation and encourage the responsibility on them in completing the tasks assigned by their teachers. Teachers are also encouraged to develop students' self-regulated learning programmatically because academic procrastination results from a failure of students in self-regulating the learning (the self-regulated learning). School administrators could use these findings in forming intake policies, for example creating a school culture 
which involves discipline, security, social relationship, and school facilities. School culture requires teachers to have commitment to their students (teacher affiliation) and to provide learning facilities and equipment. A healthy school culture increases students' academic achievement, and finally results in lower academic procrastination.

\section{References}

Asikhia, O. A. (2010). Academic Procrastination in Mathematics: Causes, Dangers, and Implications of Counselling for Effective Learning. International Education Studies, 3(3), 205-210. https://doi.org/10.5539/ies.v3n3p205

Asri, D. N. (2016). The Effect of Self-Regulated Learning, School Culture and Gender on Academic Procrastination of Junior High School Students. In DYP. Sugiharto (Ed.), $1^{\text {st }}$ Semarang State University International Conference on Counseling and Educational Psychology (pp. 122-129). Semarang, Indonesia: Semarang State University.

Babadogan, C. (2010). The impact of academic procrastination behaviors of the students in the certificate program in English language teaching on their learning modalities and academic achievements. Social and Behavioral Sciences. 2. https://doi.org/10.1016/j.sbspro.2010.03.499

Behrozi, N., Yeilagh, M. S., \& Mansourian, A. (2013). The Relationship between Self-Regulated Learning Strategies, Motivastional Learning Strategies, Procrastination and Academic Performance among the First Grade of High School Male Students in Boushehr. Journal Life Science and Biomedicine, 3(4), 277-284. Retrieved from http://ijsb.science-line.com

Bell, C. V., \& Pape, S. J. (2014). Scaffolding the development of self-regulated learning in mathematics classrooms. Middle School Journal, 45(4), 23-32. https://doi.org/10.1080/00940771.2014.11461893

Burka, J., \& Yuen, L. (1983). Mind Games Procrastinators Play. Psychology Today, 32-34.

Deniz, M. E., Traz, Z., \& Aydogen, D. A. (2009). Investigation of Academic Procrastination, Locus of Control, and Emotional Intelligence. Educational Sciences: Theory and Practice, 9(2), 623-632. Retrieved from http://www.files.eric.ed.gov/fulltext/EJ847770.pdf

Eerde, W. E. (2003). Procrastination at Work and Time Management Training. The Journal of Psychology, 137(5), 421-434. http://doi.org/10.1080.00223980309600625

Ferrari, J. R., Johnson, J. L., \& McCown, W. G. (1995). Procrastination and Task Avoidance. Theory, Research, and Treatment (Snyder, C. R., Ed.). New York: Plenum Press. https://doi.org/10.1007/978-1-4899-0227-6

Gafni, R., \& Geri, N. (2010). Time Management: Procrastination Tendency in Individual and Collaborative Tasks. Interdisciplinary Journal of Information, Knowledge, and Management, 5, 115-125. Retrieved from http://www.ijikm.org

Gottfredson, G. D., Gottfredson, D. C., Payne, A. A., \& Gottfredson, N. C. (2005). School climate predictors of school disorder: Results from a national study of delinquency prevention in schools. Journal of research in Crime \& Delinquency. 42(4), 412-444. https://doi.org/10.1177/0022427804271931

Haghbin, M., Mccaffrey, A., \& Phychyl, T. A. (2012). The Complexity of the Relation between Fear of Failure and Procrastination. Journal of Rational-Emotive \& Cognitive-Behavior Therapy, 30(4), 249-253. https://doi.org/10.1007/s10942-012-0153-9

Haycock, L. A., McCarthy, P., \& Skay, C. L. (1998). Procrastination in College Students: The Role of Self-Efficacy and Anxiety. Journal of Counseling and Development, 76(3), 317-324. https://doi.org/10.1002/j.1556-6676.1998.tb02548.x

Hoy, W. K. \& Hannum, J. W. (1997). Middle school climate: An empirical assessment of organizational health and student achievement. Educational Administration Quarterly, 33. Retrieved from https://doi.org/10.1177/0013161X97033003003

Klassen, R. M., Krawchuck, L. L., \& Rajani, S. (2008). Academic procrastination of undergraduates: Low self-efficacy to self-regulate predicts higher levels of procrastination. Contemporary Educational Psychology, 33, 915-931. https://doi.org/10.1016/j.cedpsych.2007.07.001

Knaus, W. (1998). Do it now! John Wiley \& Sons, USA.

Libbey, H. (2004). Measuring student relationship to school: Attachment, bonding, connectedness, and engagement. Journal of School Health, 74(7), 274-283. https://doi.org/10.1111/j.1746-1561.2004.tb08284.x 
Miles, M. B., Huberman, A. M., \& Saldana, J. (2014). Qualitative Data Analysis. SAGE Publications, New York Miles.

Milgram, N., \& Toubiana, Y. (1999). Academic anxiety, academic procrastination, and parental involvement in students and their parents. British Journal of Educational Psychology, 69, 345-361. https://doi.org/10.1348/000709999157761

Motie, H., Heidari, M., \& Sadhegi, M. A. (2013). Develoment of A Self-Regulation Package For Academic Procrastination and Evaluation of Its Effectiveness. The European Journal of Social \& Behavioural Sciences. http://dx.doi.org/10.15405/FutureAcademy/ejbs(2301-2218).2012.4.21

Park, S. W., \& Sperling, R. A. (2012). Academic Procrastinators and Their Self-Regulation. Scientific Research, 3(1), 12-23. https://doi.org/10.4236/psych.2012.31003

Patrzek, J., Grunschel, C., \& Fries, S. (2012). Academic Procrastination: The Perspective of University Counsellors. International Journal Adv Counselling, 34, 185-201. https://doi.org/10.1007/s10447-012-9150-z

Procee, R., Kamphorst, B., Wissen, A., \& John-Jules. (2013). A formal model of procrastination. Journal Rational-Emotive \& Cognitive-Behavior Therapy, 30, 1-15. https://doi.org/10.1007/s10447-012-9150-z

Pychyl, T. A., Coplan, R. J., \& Reid, P. A. M. (2002). Parenting and procrastination: gender differences in the relations between procrastination, parenting style and self-worth in early adolescence. Online of Personality and Individual Differences, 33, 271-285. https://doi.org/10.1016/S0191-8869(01)00151-9

Saleem, M., \& Rafique, R. (2012). Procrastination and Self-Esteem among University Students. Pakistan Journal of Social and Clinical Psychology, 9(3), 50-53. Retrieved from http://www.questia.com

Schraw, G. Wadkins, T., \& Olafson, L. (2007). Doing the things we do: A grounded theory of academic $\begin{array}{lllll}\text { procrastination. Journal of Educational Psychology, } & 99(1), & \text { 12-25. }\end{array}$ https://doi.org/10.1037/0022-0663.99.1.12

Seperiah, F., \& Lotf, J. J. (2011). The Effects of Coping Styles and Gender on Academic Procrastination among University Students. Journal of Basic and Applied Scientific Research, 1(12), 2987-2993. Retrieved from http://www.textroad.com

Tice, D. M., \& Baumeister, R. F. (1997). Longitudinal study of procrastination, performance, stress, and health: The Cost and benefits of Dawdling. Psychological Science, 8(6), 454-458. https://doi.org/10.1111/j.1467-9280.1997.tb00460.x

Tsai, C. W., Shen, P. D., \& Lee, T. H. (2011). The Effect of Combined Training of Web-Based Problem-Based Learning and Self-Regulated Learning. International Journal of Web-Based Learning and Technologies, 6(2), 40-50. https://doi.org/10.4018/jwltt.2011040103

Vahedi, S., \& Mortazanajad, H. (2009). Self-Regulation and Dimensions of Parenting Styles Predict Psychological Procrastination of Undergraduate Students. Iran Journal Psychiatry, 4. Retrieved from http://www.ijps.tums.ac.ir

Vahedi, S., Farrokhi, F., Gahramani, F., \& Issazadegan, A. (2012). The Relationship Between Procrastination, Learning Strategies and Statistic Anxiety Among Iranian College Students: A Canonical Correlation Analysis. Iran Journal Psychiatry Behavior Science, 6(1). Retrieved from https://www.ncbi.nlm.nih.gov

Wilson, B. A. (2012). Belonging to Tomorrow: An Overview of Procrastination. International Journal of Psychological Studies, 4(1), 221-217. https://doi.org/10.5539/ijps.v4n1p211

Wolters, C. A. (2003). Understanding procrastination from a self-regulated learning perspective. Journal of Educational Psychological, 95(1), 179-187. https://doi.org/10.5539/ijps.v4n1p211

Zakeri, H., Esfahani, B. N., \& Razmjoee, M. (2013). Parenting Styles and Academic Procrastination. Online Journal of Social and Behavioral Sciences, 84, 57-60. https://doi.org/10.1016/j.sbspro.2013.06.509

Zeenath, S., \& Orcullo, D. J. C. (2012). Exploring Academic Procrastination among Undergraduates. https://doi.org/10.7763/IPEDR.2012.V47.9

Zullig, K. J., Koopman, T. M., Patton, J. M., \& Ubbes, V. A. (2010). School Climate: Historical Review, Instrument Development, and School Assessment. Journal of Psychoeducational Assessment, 28(2). https://doi.org/10.1177/0734282909344205 


\section{Copyrights}

Copyright for this article is retained by the author(s), with first publication rights granted to the journal.

This is an open-access article distributed under the terms and conditions of the Creative Commons Attribution license (http://creativecommons.org/licenses/by/4.0/). 